\title{
The Digestibility of Nutrients of Natural Diet by European Bison in Different Seasons
}

\section{Jan KOWALCZYK, Zofia GĘBCZYŃSKA \& Małgorzata KRASIŃSKA}

Kowalczyk J., Gębczyńska Z. \& Krasińska M., 1976: The digestibility of nutrients of natural diet by European bisons in different seasons. Acta theriol., 21, 8: 141-146. [With 3 Tables].

Experiments were carried out with two 3 and 4 years old European bisons. The digestibility of nutrients and energy was estimated of diets composed of plants eaten by free-living bisons at different time of the year. The diet contained: in spring - willow, hornbeam and aspen browse and blueberry bushes; in summer - fresh grass and herbs and willow bark; in autumn - dried grass and browse. Values for digestibility coefficients in spring, summer and autumn were, respectively: dry matter - 55.6, 60.6, 51.6, crude protein - 59.4, 56.0, 38.9, crude fibre - 35.4, 56.4, 46.8, cellulose - 52.6, 66.5, 56.2, lignin - 30.1, 32.0, 27.4 and energy - 56.5, 61.6, 49.5. Soluble sugars were completely digested.

[Inst. Anim. Physiol., Polish Acad. Sci., 05-110 Jabłonna (JK), and Mammals Res. Inst., Polish Acad. Sci., 17-230 Białowieża (ZG, MK)].

\section{INTRODUCTION}

Numerous studies were conducted recently on the hoofed animals (European bison, roe deer, red deer) of the virgin forest of Białowieża to provide information on the role of these animals in the forest ecosystem. The kinds and quantities of ingested feeds were estimated in studies on the feeding habits of the European bison (B a škirov, 1939; Z a bl o c ka ja, 1957; K o r oc k i n a, 1966, 1969 a, b; B o r o ws k i et al., 1967; B or owski \& K os s a k, 1972, 1975; G ę b c z yńska

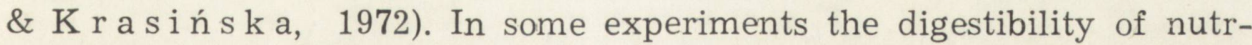
ients were estimated but the feeds given differed considerably from the natural diet of free-living bisons ( $\mathrm{Sz}$ aniawski, 1959; Gę bczyńsk a et al., 1974; P e d e n et al., 1974).

The purpose of the present experiment was to estimate the digestibility of nutrients and energy of the natural diet of free-living bisons.

\section{MATERIAL AND METHOD}

The experiment was conducted in three different seasons: in May, in June-July and in October with two bisons captured in the forest: Kalif (Pedigree No. 2753, live weight $290 \mathrm{~kg}$ ) 3 years old, and Karat (Pedigree No. 2752, live weight $385 \mathrm{~kg}$ ) 
4 years old. The bisons were placed in a 10 ha large, enclosed forest reserve of the Mammals Research Institute in Białowieża. During the experiment the animals were kept in individual pens, $135 \mathrm{~m}^{2}$ large, with concrete floor.

In succesive digestibility trials diets were given composed of natural feeds derived from the forest. The diet composition differed depending on the season and was based on the studies of B or owski \& Kos s a k (1972). It consisted of plants readily accesible and eaten by the animals under natural conditions: in spring - willow, hornbeam and aspen browse and blueberry bushes; in summer - fresh grasses and herbs and willow bark, and in autumn grasses and browse in proportion shown in Table 1. In spring and summer the feed was gathered daily early in the morning and given on the same day. In autumn the feed was harvested in September, air-dried and stored for subsequent use.

Table 1

Average composition of rations $(\%)$ and daily intake $(\mathrm{kg})$.

\begin{tabular}{|c|c|c|c|}
\hline & \multicolumn{3}{|c|}{ Seasons } \\
\hline & I - spring & II - summer & III - autumn \\
\hline Carpinus betulus (twigs with leaves) & 20.6 & - & 9.9 \\
\hline Salix caprea (twigs with leaves) & 25.9 & - & 16.4 \\
\hline Salix caprea (bark) & 13.8 & 9.6 & - \\
\hline Vaccinium myrtillus & 13.8 & - & 9.8 \\
\hline Populus tremula (twigs with leaves) & 25.9 & - & 9.8 \\
\hline Urtica dioica & - & 11.3 & 9.8 \\
\hline Impatiens noli-tangere & - & 11.3 & - \\
\hline Cirsium oleraceum & - & 22.6 & 9.8 \\
\hline Ranunculus lanuginosus & - & 11.3 & - \\
\hline Cirsium sp. & - & 11.3 & -- \\
\hline Gramineae & - & 11.3 & - \\
\hline Aegopodium podagraria & - & 11.3 & - \\
\hline Gramineae (hay) & - & - & 24.6 \\
\hline Rubus idaeus & - & - & 9.9 \\
\hline \multicolumn{4}{|c|}{ Intake per day, $\mathrm{kg}$ (in brackets - dry matter intake) } \\
\hline Kalif & $12.0(3.8)$ & $27.0(4.4)$ & $8.4(6.4)$ \\
\hline Karat & $17.0(5.4)$ & $35.0(5.7)$ & $9.9(7.3)$ \\
\hline
\end{tabular}

The diet was given in two equal meals per day: at $08^{\circ \circ}$ and $16^{\circ \circ} \mathrm{h}$. The amount given depended on the liveweight of the animal and was chosen so that the feed was eaten completely (Table 1). The animals had free access to water.

In each trial a 10 day preliminary period, during which the amount of feed was established, was followed by a 6 day collection period. The faeces were collected quantitatively after each excretion and representative samples were analysed. The proximate composition of feeds and faeces was estimated by conventional methods. Apart from that, soluble sugars, readily hydrolysable carbohydrates, cellulose and lignin were determined as described by. $\mathrm{H}$ off $\mathrm{man}$ et al. (1969) and the content of hemicellulose was assessed from the difference between total carbohydrates and estimated fractions. The digestible energy of the diet was calculated from the difference between the gross energy of feeds and faeces, their energy contents being calculated from the chemical composition, using the equations of Nehring et al. (1970). 


\section{RESULTS}

In spite of the widely different botanical composition of the diets given at different time of the year (Table 1) the contents of nutrients in the dry matter were similar (Table 2).

Table 2

Chemical composition of rations, $\%$

\begin{tabular}{lccc}
\hline & \multicolumn{3}{c}{ Seasons } \\
\cline { 2 - 4 } & I - spring & II - summer & III - autumn \\
\hline Dry matter & 31.82 & 16.36 & 74.02 \\
In dry matter: & & & \\
Ash & 5.42 & 10.25 & 9.43 \\
Organic matter & 94.58 & 89.75 & 90.57 \\
Crude protein & 14.31 & 11.63 & 12.05 \\
Ether extract & 4.28 & 2.99 & 3.11 \\
Crude fibre & 22.19 & 25.92 & 26.05 \\
N-free extractives & 53.80 & 49.21 & 49.36 \\
Carbohydrates: & & & \\
Soluble sugars & 3.33 & 4.03 & 5.23 \\
Readily hydrolysable carbohydrates & 1.73 & 1.59 & 1.45 \\
Cellulose & 26.12 & 28.79 & 26.86 \\
Lignin & 24.67 & 19.25 & 19.87 \\
Hemicellulose & 20.14 & 21.46 & 22.00 \\
Gross energy per 1 kg of DM, kcal & 3175 & 4249 & 4291 \\
\hline
\end{tabular}

Table 3

Apparent digestiblity coefficients of nutrients of the rations (averages and mean deviations).

\begin{tabular}{lccc}
\hline & \multicolumn{3}{c}{ Seasons } \\
\cline { 2 - 4 } & I - spring & II - summer & III - autumn \\
\hline Dry matter & $55.6 \pm 0.4$ & $60.6 \pm 1.3$ & $51.6 \pm 1.1$ \\
Ash & $37.4 \pm 2.9$ & $35.1 \pm 0.7$ & $31.1 \pm 2.7$ \\
Organic matter & $59.1 \pm 0.5$ & $63.5 \pm 1.5$ & $53.8 \pm 1.5$ \\
Crude protein & $59.4 \pm 0.1$ & $56.0 \pm 0.8$ & $38.9 \pm 1.9$ \\
Ether extract & $21.7 \pm 0.6$ & $28.1 \pm 2.9$ & $17.0 \pm 4.2$ \\
Crude fibre & $35.4 \pm 1.0$ & $56.4 \pm 1.9$ & $46.8 \pm 1.2$ \\
N-free extractives & $71.4 \pm 0.7$ & $71.1 \pm 1.5$ & $63.4 \pm 1.3$ \\
Soluble sugars & 100 & 100 & 100 \\
Readily hydrolysable carbohydrates & $72.3 \pm 0.3$ & $73.9 \pm 1.3$ & $73.5 \pm 5.7$ \\
Cellulose & $52.6 \pm 0.2$ & $66.5 \pm 1.9$ & $56.2 \pm 1.2$ \\
Lignin & $30.1 \pm 0.1$ & $32.0 \pm 3.9$ & $27.4 \pm 6.7$ \\
Hemicellulose & $99.8 \pm 0.2$ & $88.9 \pm 0.4$ & $75.1 \pm 3.6$ \\
Gross energy & $56.5 \pm 0.5$ & $61.6 \pm 1.3$ & $49.5 \pm 1.5$ \\
\hline
\end{tabular}

Digestibility coefficients of nutrients and energy are presented in Table 3 . The digestibility of crude protein was highest in spring, of dry matter, crude fibre and cellulose in summer. The digestiblity of energy was highest with the summer diet. 


\section{DISCUSSION}

The results have shown differences in the utilization of nutrients and energy of the diet by bisons, depending of the season. The spring and summer diet consisted largely of young twigs and grasses with a high content of soluble nitrogenous constituents, amides and free amino acids and, consequently, the digestibility of crude protein in these seasons was higher than in autumn. The situation was similar with regard to the digestibility of crude fibre, cellulose and $\mathrm{N}$-free extractives. Seasonal changes in the digestiblity of these constituents affected indirectly the digestibility values of dry matter and organic matter. Seasonal changes in dry matter digestibility of the rations offered to bisons were observed also in the experiment of $\mathrm{P}$ e d e $\mathrm{n}$ et al. (1974).

The soluble sugars were completely digested, in accord with the results of previous experiments (K ow a lc zy k et al., 1969; Prins \& G e eln, 1971; G ę b c z yńska et al., 1974). On the other hand, the digestibility of readily hydrolysable carbohydrates was rather low, $74 \%$, irrespective of season. A possible explanation is that certain amounts of undigested bacterial cells and endogenous glycoproteins are being excreted in the faeces and the sugars, forming part of this material, are released in the course of the estimation of readily hydrolysable carbohydrates. If, as was the case with our experiment, the diet contains little readily hydrolysable carbohydrates (about $1.5 \%$ ) then the sugars contained in the bacteria and glycoproteins excreted in faeces are likely to reduce the apparent digestibility of this carbohydrate fraction, in spite of the fact that the readily hydrolysable carohydrates of the diet are completely metabolised in the rumen.

The high digestibility of lignin observed in all seasons is consistent with the results of previous experiments on bisons (Gę bczynska et al., 1974). The problem of lignin digestiblity is still controversial but numerous studies seem to suggest that it can be digested by cattle to a certain extent, depending on the kind and stage of maturity of the plants, composition of the diet etc. but the digestibility in cattle is less than in European bisons (Maynard \& Loosli, 1967; J ohnson, 1972; Verme \& Ullrey, 1972; Gębczyńska et al., 1974). The technique of lignin estimation may also influence the digestibility values (Van S o e s t, 1964).

The utilization of energy of the diet differed depending on the season and was least in autumn (Table 3). This is not surprising, as at this time of the year the feed contained a considerable proportion of undigestible constituents and the intake of dry matter was greater than in the other seasons (Table 1). The natural diet was well utilised by the bisons as 
indicated by relatively high digestibility values, in spite of the fact that the diet consisted largely of browse and bark of trees and shrubs. The ability to digest lignin suggest specific adaptation of the bison to its natural environment, the woodland, and the lignin-rich material it feeds on. This adaptation has not been affected by long years of breeding in the reserve, where the bisons are fed largely on feeds similar to those used for domestic cattle.

A practical suggestion for bison breeders in reserves and zoological gardens is evident from this study: the natural feeds for late autumn and wintertime should be harvested during late spring and summer. The digestibility of these feeds is better than when gathered at a later time. This applies primarily to browse i.e. well leafed twigs of no more than $1 \mathrm{~cm}$ diameter which are then air-dried.

\section{REFERENCES}

1. B a škir o v I., 1939: Kavkazkij zubr. Glav. Upravl. po Zap., Zoopark. i Zoosad. S.N.K. RSFSR: 1-72. Moskva.

2. Borowski S. \& Kossak S., 1972: The natural food preferences of the European bison in season free of snow cover. Acta theriol., 17, 13: 151-169.

3. Borowski S. \& Kossak S., 1975: Food habits of deer in Białowieża Primeval Forest. Acta theriol., 20, 32: 463-506.

4. Borowski S., Krasiński Z. \& M iłkowski L., 1967: Food and role of the European bison in forest ecosystems. Acta theriol., 12, 25: 367-376.

5. Gębczyńska Z., Kowalczyk J., Krasińska M. \& Ziołecka A., 1974: A comparison of the digestibility of nutrients by European bison and cattle. Acta theriol., 19, 19: 283-289.

6. Gębczyńska Z. \& Krasińska M., 1972: Food preferences and requirements of the European bison. Acta theriol., 17, 10: 105-117.

7. Hof $\mathrm{fmann}$ B. \& $\mathrm{Nehr}$ ing K., 1969: Untersuchungen zur Weiterentwicklung der Futtermittelanalyse. Mitt. 2. Die Bestimmung der Kohlenhydrate in den Futtermitteln. Arch. Tierernähr., 19, 9: 651-670.

8. Johnson R. R., 1972: Feedstuffs utilized by ruminants. [In: „Digestive physiology and nutrition of ruminants«, Ed. D. C. Chu r c h]. 3: 9-34. Oregon.

9. K o r o čkin a L. N., 1966: K voprosu o značenii drevesnoj rastitelnosti v pitani zubrov Belovežskoj Pušči. Vesci AN BSSR, 1: 106-111.

10. Koročkina L. N., 1969a: Vidovoj sostav lesnoj travianistoj rastitelnosti v pitanii zubrov Belovežskoj Pušči. Belovežskaja Pušča, Issledovanija, 3: 204$-221$.

11. K or očkin a L. N., 1969b: Drevesnaja rastitelnost $\mathrm{v}$ pitanii zubrov Belovežskoj Pušči. Belovežskaja Pušča, Issledovanija, 3: 120-126.

12. Kowalczyk J., Ramirez A. \& Geerken C. M., 1969: Studies on composition and flow of duodenal contents in cattle feed diets high in molasses and urea. Rev. cub. Scienc. Agric., 3: 221-226.

13. M a y n a d L. A. \& Loosli J. K., 1967: Naukowe podstawy żywienia zwierząt. PWRL. Warszawa. Str. 68. 
14. Nehring K., B e yer M. \& $\mathrm{H}$ of $\mathrm{fmann}$ B., 1970: Futtermitteltabellenwerk. DLV. Berlin.

15. Peden D. G., Van Dyne G. M., Rice R. W. \& Hansen R. M., 1974: The trophic ecology of Bison bison L. on shortgrass plains. J. appl. Ecol., 11: 489-498.

16. Prins R. A. \& Ge elen M. J. H., 1971: Rumen characteristics of red deer, fallow deer and roe deer. J. Wildl. Manage., 35, 4: 673-680.

17. Szaniawski A., 1959: Comparison of digestibility of feedingstuffs with different protein rations for calves of domestic cattle and of bison, Bison bonasus (L.). Acta theriol., 3, 13: 318-319.

18. Van Soest P. J., 1964: Symposium on nutrition and forage and pastures: new chemical procedures for evaluating forages. J. Animal. Sci., 23, 3: 838-845 .

19. Verme L. J. \& Ullrey D. E., 1972: Feeding and nutrition of deer. [In: "Digestive physiology and nutrition of ruminants", ed. D. C. Church]. 3: $275-291$.

20. Zablockaja L. V., 1957: Pitanije i estestvennaja korma zubrov. Trudy prioksko-terras. gos. Zap., 1: 66-143.

Accepted, March 25, 1975.

Jan KOWALCZYK, Zofia GĘBCZYŃSKA i Małgorzata KRASIŃSKA

\section{STRAWNOŚ́ SKŁADNIKÓW POKARIMOWYCH PASZ NATURALNYCH POBIERANYCH PRZEZ ŻUBRY W RÓŻNYCH PORACH ROKU}

\section{Streszczenie}

W doświadczeniach przeprowadzonych w Puszczy Białowieskiej na dwóch 3-4 letnich żubrach określono współczynniki strawności składników pokarmowych oraz energii dawek złożonych $\mathrm{z}$ roślin pobieranych przez żubry żyjące na wolności w trzech sezonach roku. W skład dawek wchodziły: wiosną - świeżo zebrane pędy iwy, grabu, osiki oraz ezarna jagoda; latem - świeże trawy i zioła oraz kora z iwy; jesienią - suche rośliny trawiaste oraz gałązki drzew i krzewów.

Współczynniki strawności w sezonie wiosennym, letnim i jesiennym wynosiły odpowiednio: sucha masa - 55.6; 60.6 ; 51.6 ; białko - 59.4; 56.0 ; 38.9 ; włókno $35.4 ; 56.4 ; 46.8$; celuloza $-52.6 ; 66.5 ; 56.2$; lignina $-30.1 ; 32.0 ; 27.4$; energia -56.5 ; $61.6 ; 49.5$. Węglowodany rozpuszczalne były całkowicie trawione przez żubry. 